\title{
PENGARUH PEMBERIAN JUS BUAH TOMAT (LYCOPERSICON ESCULENTUM MILL.) TERHADAP PEMBERSIHAN STAIN EKSTRINSIK PADA RESIN KOMPOSIT
}

\author{
${ }^{1}$ Kartika Ibrahim \\ ${ }^{2}$ Shirley E. S. Kawengian \\ ${ }^{3}$ Paulina N. Gunawan \\ ${ }^{1}$ Kandidat Skripsi Fakultas Kedokteran Universitas Sam Ratulangi \\ ${ }^{2}$ Bagian Gizi Fakultas Kedokteran \\ ${ }^{3}$ Progran Studi Pendidikan Dokter Gigi Fakultas Kedokteran \\ Universitas Sam Ratulangi Manado \\ Email: kartika_ibrahim1994@gmail.com
}

\begin{abstract}
Discoloration of the composite resin is an aesthetic problem that often occurs primarily in anterior teeth caused by extrinsic and intrinsic factors. Bleaching is a kind of treatment that can improve the problem of composite discoloration. One of the bleaching materials oftenly used in dentistry is $\mathrm{H} 2 \mathrm{O} 2$. $\mathrm{H} 2 \mathrm{O} 2$ compound contained in tomatoes can be used as an alternative treatment to cope with the composite discoloration. This study aimed to determine the effect of tomato juice as extrinsic stain cleaner of the composite resin. This was a laboratory experimental study with a pre and post control group design. Samples were 20 resin composites molded in $5 \mathrm{~mm}$ diameter and $2 \mathrm{~mm}$ thickness. Samples were soaked in coffee solution for 10 days to get the extrinsic stain and then discoloration was measured with a spectrophotometer discoloration Libra S12 UV / Visible Biochrom. After that, samples were divided into 2 groups: the control group, immersed in mineral water; and the treatment group, immersed in tomato juice for 3 days. After immersion, measurements were done again with a spectrophotometer. The results were tested statistically using the Wilcoxon test with a $P$ value $<0.05$. Conclusion: Tomato juice was a significant extrinsic stain cleaner of the composite resin.
\end{abstract}

Keywords: tomato juice, extrinsic stain, resin composites

\begin{abstract}
Abstrak: Perubahan warna tumpatan komposit merupakan masalah estetik yang sering terjadi terutama pada gigi anterior yang disebabkan oleh faktor ekstrinsik dan intrinsik. Salah satu perawatan untuk menangani masalah ini ialah bleaching dengan $\mathrm{H} 2 \mathrm{O} 2$. Senyawa $\mathrm{H} 2 \mathrm{O} 2$ terkandung dalam buah tomat yang dapat digunakan sebagai perawatan alternatif untuk mengatasi perubahan warna komposit. Penelitian ini bertujuan untuk mengetahui pengaruh pemberian jus buah tomat terhadap pembersihan stain ekstrinsik pada resin komposit. Jenis penelitian ini ialah eksperimental laboratorium dengan desain pre and post control group. Jumlah sampel penelitian 20 resin komposit yang dibentuk dengan diameter $5 \mathrm{~mm}$ dan tebal $2 \mathrm{~mm}$. Sampel direndam dalam larutan kopi selama 10 hari untuk melihat adanya stain ekstrinsik kemudian dilakukan pengukuran perubahan warna dengan spektrofotometer Libra S12 UV/Visible BIOCHROM. Setelah itu sampel dibagi menjadi 2 kelompok, yaitu kelompok kontrol direndam dalam air mineral dan kelompok perlakuan di dalam jus buah tomat selama 3 hari. Setelah perendaman dilakukan pengukuran kembali dengan spektrofotometer. Hasil penelitian diuji secara statistik dengan uji Wilcoxon mendapatkan nilai $P<0,05$. Simpulan: Jus buah tomat berpengaruh secara bermakna terhadap pembersihan stain ekstrinsik pada resin komposit.
\end{abstract}

Kata kunci: jus buah tomat, stain ekstrinsik, resin komposit 
Stain atau pewarnaan pada gigi merupakan salah satu masalah yang mengganggu penampilan. Secara estetik masalah tersebut merupakan yang paling sering muncul sebagai keluhan terutama pada gigi anterior pasien. Stain dapat disebabkan oleh faktor ekstrinsik seperti makanan, minuman, atau konsumsi rokok serta obatobatan tertentu yang meninggalkan perlekatan stain pada permukaan gigi, serta faktor intrinsik yang berasal dari bagian dalam struktur gigi selama odontogenesis atau setelah erupsi gigi. ${ }^{1}$

Perubahan warna tidak hanya dapat terjadi pada permukaan gigi, tetapi juga dapat terjadi pada permukaan tumpatan pada gigi. Pada saat ini tumpatan komposit banyak menjadi pilihan pasien maupun dokter gigi untuk digunakan sebagai tumpatan gigi anterior dalam memenuhi kebutuhan estetik pasien karena warna tumpatan tersebut sewarna dengan gigi. ${ }^{1,2}$

Seperti pada gigi, perubahan warna juga dapat terjadi pada tumpatan komposit yang disebabkan oleh beberapa faktor, antara lain kandungan makanan, minuman, maupun rokok yang dikonsumsi secara berlebihan sehingga mudah meninggalkan stain pada permukaan gigi maupun permukaan tumpatan komposit. ${ }^{1,2}$ Mengonsumsi minuman kopi secara berlebihan merupakan salah satu penyebab munculnya stain secara ekstrinsik. ${ }^{1}$ Sebelumnya telah dilakukan penelitian serupa yang membuktikan bahwa stain bisa muncul pada permukaan resin komposit pada perendaman dalam larutan kopi dengan waktu minimal 5 hari. ${ }^{3}$ Buah tomat (Lycopersicon esculentum Mill.) merupakan tanaman yang telah dikenal manusia sejak dahulu dan mudah dijumpai. Senyawa hidrogen peroksida yang dikenal sebagai bleaching agent yang dapat mereduksi stain pada permukaan gigi berhasil diidentifikasi dalam buah tomat. ${ }^{4}$

Penelitian sebelumnya telah membuktikan adanya efektivitas jus buah tomat terhadap perubahan warna gigi pada proses pemutihan gigi secara in vitro dengan metode perendaman selama 3 hari. $^{5}$ Penelitian serupa juga telah dilakukan dengan metode penyikatan menggunakan pasta ekstrak tomat pada gigi tiruan dan plat resin akrilik dan dapat membuktikan efektivitas pasta ekstrak tomat mereduksi stain ekstrinsik. ${ }^{6}$ Adapun penelitian lain yang membuktikan efek bleaching dari buah tomat dengan metode smear dan inkubasi selama 3 hari. $^{7}$ Beberapa penelitian tersebut mendorong peneliti untuk mengembangkan penelitian mengenai buah tomat sebagai alternatif lain dalam perawatan bleaching khususnya pada tumpatan komposit dengan harapan dapat membuktikan perubahan warna secara signifikan dan bermakna.

\section{BAHAN DAN METODE PENELITIAN}

Penelitian ini menggunakan sampel 20 buah resin komposit nanofiller (A3) yang dibentuk tablet dengan diameter $5 \mathrm{~mm}$ dan tebal $2 \mathrm{~mm}$. Seluruh sampel diukur warna kecerahan awalnya dengan spektrofotometer. Kemudian seluruh sampel direndam pada larutan kopi di dalam gelas selama 10 hari untuk melihat adanya stain ekstrinsik. Setelah perendaman pada kopi dilakukan pengukuran perubahan warna kembali dengan spektrofotometer. Siapkan 100 g buah tomat yang dicuci bersih dan disajikan dalam bentuk jus dimasukkan ke dalam wadah yang telah diberi label A (kelompok intervensi) dan siapkan air mineral kemasan sebanyak 100ml ke dalam wadah dengan label B (kelompok kontrol). Setelah itu sampel dibagi menjadi 2 kelompok, masing-masing 10 buah sampel untuk perendaman pada kelompok kontrol (air mineral) dan kelompok perlakuan (jus buah tomat) masing-masing selama 3 hari. Setelah perendaman seluruh sampel dilakukan pengukuran kembali dengan spektrofoto-meter.

\section{HASIL PENELITIAN}

Tabel 1 memperlihatkan nilai rerata kecerahan seluruh hasil pengukuran perubahan warna setiap perlakuan pada sampel. Tabel 2 menunjukkan hasil analisis perubahan warna sampel setelah perendaman pada kelompok intervensi maupun kelompok kontrol. 
Tabel 1. Nilai Rerata Kecerahan Seluruh Hasil Pengukuran

\begin{tabular}{lc}
\hline Perlakuan sampel & $\begin{array}{c}\text { Nilai Rerata } \\
\text { kecerahan (ppm) }\end{array}$ \\
\hline $\begin{array}{l}\text { Sebelum perendaman } \\
\text { Setelah perendaman }\end{array}$ & 2,16 \\
dalam kopi & 0,79 \\
$\begin{array}{l}\text { Setelah perendaman } \\
\text { dalam jus buah tomat }\end{array}$ & 1,48 \\
$\begin{array}{l}\text { Setelah perendaman } \\
\text { dalam air }\end{array}$ & 0,81 \\
\hline
\end{tabular}

Tabel 2. Hasil analisis perubahan warna sampel

\begin{tabular}{lccc}
\hline Perlakuan & $\mathrm{n}$ & Rerata \pm s.b. & $p$ \\
\hline $\begin{array}{l}\text { Setelah perendaman } \\
\text { pada kopi }\end{array}$ & 20 & $0,78 \pm 0,19$ & \\
$\begin{array}{l}\text { Setelah perendaman } \\
\text { pada jus tomat }\end{array}$ & 10 & $1,48 \pm 0,32$ & 0,005 \\
$\begin{array}{l}\text { Setelah perendaman } \\
\text { pada air }\end{array}$ & 10 & $0,81 \pm 0,19$ & 0,343 \\
\hline
\end{tabular}

Hasil rerata nilai kecerahan didapat dari penjumlahan nilai selisih yang dihasilkan panjang gelombang 645 dengan panjang gelombang 633 dan kemudian diambil rata-rata dari setiap pengukuran sampel. Semakin tinggi nilai yang didapat maka semakin tinggi juga kecerahannya. Nilai rerata kecerahan sampel setelah direndam dalam kopi menunjukkan adanya perubahan warna pada sampel dengan selisih nilai rerata 1,37 dengan nilai rerata kecerahan awal sampel. Perubahan warna juga terjadi pada sampel setelah dilakukan perendaman dalam jus buah tomat maupun air. Hal ini menunjukkan adanya perubahan warna setelah dilakukan beberapa perlakuan pada sampel dengan terjadinya penurunan serta peningkatan nilai kecerahan sampel baik secara visual maupun secara instrumental. Untuk mengetahui seberapa signifikan pengaruh dari perlakuan pada kelompok intervensi maupun kelompok kontrol maka perlu dilakukan uji statistik pada masing-masing kelompok.

Dari hasil analisis uji statistik Wilcoxon diketahui bahwa seluruh sampel pada kelompok intervensi memiliki skor positif, yang artinya seluruh skor pada data sesudah perendaman pada jus tomat lebih besar dari skor pada data sesudah perendaman dalam kopi. Hal ini menunjukkan ada perubahan skor positif pada kelompok intervensi. Begitu juga dengan nilai signifikansi $p$ sebesar 0.005 $(<0.05)$ maka dapat disimpulkan bahwa terdapat pengaruh jus buah tomat yang bermakna terhadap pembersihan stain ekstrinsik pada resin komposit.

Uji statistik pada kelompok kontrol menggunakan uji $t$ berpasangan untuk melihat ada atau tidaknya pengaruh antara dua kelompok berpasangan. Oleh karena hasil uji normalitas dengan Shapiro Wilk menunjukkan data kelompok kontrol berdistribusi normal maka digunakan uji statistik parametrik yaitu uji t berpasangan. Berdasarkan hasil analisis uji statistik $\mathrm{t}$ berpasangan dengan tambahan informasi median, rerata dan simpang baku pada data kelompok kontrol, diketahui bahwa nilai $p$ adalah 0,343. Oleh karena nilai $\mathrm{p}>0,05$ maka dapat disimpulkan bahwa tidak terdapat pengaruh pemberian air terhadap pembersihan stain ekstrinsik pada resin komposit. Hasil analisis uji statistik kelompok kontrol juga dapat digunakan untuk melihat perbedaan pengaruh dengan hasil analisis uji statistik kelompok intervensi. Dengan demikian dapat disimpulkan bahwa air tidak memiliki pengaruh yang bermakna terhadap pembersihan stain ekstrinsik pada resin komposit.

\section{BAHASAN}

Hasil perendaman sampel resin komposit dalam jus buah tomat selama 3 hari menunjukkan adanya pengaruh yang bermakna terhadap pembersihan stain ekstrinsik pada resin komposit. Hal ini dapat dilihat dari hasil pengukuran spektrofotometer yang menunjukkan terjadinya peningkatan nilai kecerahan pada sampel kelompok intervensi sedangkan pada kelompok kontrol tidak menunjukkan adanya pengaruh yang bermakna terhadap nilai kecerahan sampel 
setelah perendaman pada kopi. Hasil penelitian ini sesuai dengan beberapa penelitian sebelumnya yang telah dilakukan dan membuktikan adanya pengaruh buah tomat sebagai bahan bleaching alternatif yang digunakan di bidang kedokteran gigi dengan waktu perendaman selama 3 hari sudah cukup maksimal untuk dapat membuktikan pengaruh yang signifikan.

Resin komposit merupakan bahan tumpatan pilihan yang telah dikembangkan sehingga dapat digunakan sebagai tumpatan gigi anterior maupun posterior. ${ }^{8}$ Bahan tumpatan ini memiliki keunggulan estetik sangat baik dibandingkan dengan bahan tumpatan lain oleh karena warna tumpatan yang sewarna dengan gigi namun sangat rentan terhadap perubahan warna. ${ }^{9}$ Perubahan warna pada komposit dapat disebabkan oleh penyerapan air dengan noda larut seperti pada larutan kopi. ${ }^{8}$

Pemutihan gigi atau bleaching merupakan suatu upaya memperbaiki gigi atau tumpatan komposit yang telah mengalami diskolorasi atau perubahan warna ekstrinsik maupun intrinsik. ${ }^{10}$ Seperti pada gigi, perawatan bleaching dapat diterapkan pada resin komposit. Material bahan bleaching dapat menembus matriks resin melalui proses oksidasi dan dapat mendegradasi agen penghasil warna pada permukaan resin. Proses degradasi ini akan menghasilkan kemampuan dari material bahan bleaching memperoleh pigmen warna pada resin komposit yang kemudian dioksidasi menjadi warna yang lebih cerah. ${ }^{11}$ Material bahan bleaching kedokteran gigi dapat mengakibatkan efek samping terutama terhadap sensitivitas gigi, serta konsentrasi bahan bleaching yang tinggi dapat menyebabkan iritasi pada jaringan lunak dalam mulut. Material bahan bleaching dapat diperoleh dari sayuran atau buah. Seperti hidrogen peroksida $\left(\mathrm{H}_{2} \mathrm{O}_{2}\right)$ yang terkandung di dalam buah tomat (Lycopersicon esculentum Mill.). ${ }^{7}$ Senyawa hidrogen peroksida terakumulasi di dalam pericarp buah tomat pada saat tomat berwarna merah. ${ }^{4}$

\section{SIMPULAN}

Terdapat pengaruh pemberian jus buah tomat (Lycopersicon esculentum Mill.) terhadap pembersihan stain ekstrinsik pada resin komposit

\section{SARAN}

Perlu adanya penelitian lebih lanjut mengenai peran buah tomat sebagai perawatan alternatif bleaching pada resin komposit khususnya manfaat praktis buah tomat agar lebih aplikatif dalam pemanfaatannya oleh masyarakat.

\section{DAFTAR PUSTAKA}

1. Rahmadhan AG. Serba Serbi Kesehatan Gigi dan Mulut. Ed. 1. Handayani NP, editor. Jakarta: Bukuné, 2010; p.73-5.

2. Ecceles JD, Green RM. Konservasi Gigi (The Conservation of Teeth) (2nd ed). Alih bahasa: Lilian Yuwono. Susianti Kentjana, editor. Jakarta: Widya Medika, 1994.

3. Manangkalangi AP. Pengaruh Lama Waktu Perendaman Kopi Terhadap Perubahan Warna pada Resin Komposit. Manado: Universitas Sam Ratulangi; 2014.

4. Jimenez A, Creissen G, Kular B, Firmin $\mathbf{J}$, Robinson S, et al. Changes in Oxidative Processes and Components of the Antioxidant System during Tomato Fruit Ripening. Planta. 2002;214(5):751-8.

5. Pratiwi SA. Pengaruh Pemberian Jus Buah Tomat (Lycopersicon esculentum Mill.) terhadap Perubahan Warna Gigi Pada Proses Pemutihan Gigi Secara In Vitro [Karya Tulis Ilmiah]. Semarang: Fakultas Kedokteran Universitas Diponegoro; 2009.

6. Pratiwi I. Pengaruh Pasta Ekstrak Tomat (Lycopersicon Esculentum Mill.) terhadap Penghilangan Stain Ekstrinsik pada Permukaan Gigi, Gigi Tiruan dan Plat Resin Akrilik [Skripsi]. Yogyakarta: Fakultas Kedokteran Gigi Universitas Gadjah Mada; 2014.

7. Mulky IH, Nada Rania, Nila Kusuma, Tsabitha SF. The Influence of Tomato Juice as an Alternative Treatment to Whiten the Teeth. ISJ. 
2014-ISJ-001-00045.

8. Sampoerno G. Effectiveness of Bleaching Agent on Composite Resin Discoloration. Dent J. (Maj. Ked. Gigi). 2012;1(45):43-7.

9. Sularsih, Sarianoferni. Penggunaan Resin Komposit Untuk Mengurangi Resiko Barodontalgia. Dental Jurnal Kedokteran Gigi FKG-UHT. 2007; 1(2):100-5.
10.Dewi K, Yuliati A, Munadziroh E. Evaluasi perubahan warna komposit hybrid setelah di rendam obat kumur. Jurnal PDGI. 2012;61(1):5-9.

11.Walton RE, Torabinejad M. Prinsip dan Praktik Ilmu Endodonsi. Ed.2. Editor: Sumawinata N. Alih Bahasa: Sumawinata N, Sidharta W, Nursangkoko B. Jakarta; EGC, 1997; p. 518-9. 